UDC 336.22

DOI: https://doi.org/10.37320/2415-3583/12.33

\author{
Kotina Hanna \\ Candidate of Economical Sciences, Associate Professor, \\ Senior Lecturer at Department of Finance, \\ Kyiv National Economic University named after Vadym Hetman \\ ORCID: https://orcid.org/0000-0001-7783-866X
}

Stepura Maryna

Candidate of Economical Sciences, Associate Professor, Senior Lecturer at Department of Finance,

Kyiv National Economic University named after Vadym Hetman ORCID: https://orcid.org/0000-0001-5881-5411

Polyvana Yulia

Master Student,

Kyiv National Economic University named after Vadym Hetman

\title{
TAXATION OF DIGITAL SERVICES AS AN ALTERNATIVE FISCAL TOOL IN THE CONTEXT OF GLOBAL TRENDS
}

The article deals with the global practice of introducing taxes on digital services and the possibility of implementation the equalization taxes in Ukraine. The purpose of creating innovations in tax system is the efficiency of revenue collection. The absence of the primary relationship between the competitiveness of the tax system and the introduction of alternative taxes - taxation of digital economy - is defined. Despite the existence of potential shortcomings, including their negative impact on growth and productivity, non-neutrality, possibilities of double taxation, and problems in compliance and administration, it is a challenge of today, a new niche in expanding the tax base, counteracting the erosion of existing tax bases in order to avoid taxation and an alternative source of budget revenue for different countries.

Key words: tax, taxation of digital services, equalization taxes, public finance, revenues, tax law.

JEL classification: H2, H21, H25, H26

Introduction. The economy of the 21 st century is characterized by the fact that firms can be actively involved in the economic life of a large number of jurisdictions without a physical presence, and new intangible factors in the cost of products or services are becoming more important. As noted in the report of the UN Conference on trade and development, the digital revolution is changing lives and societies at an unprecedented speed and scale, while creating both huge opportunities and enormous challenges. Global digitalization has not only forced companies to seek new competitive advantages in the digital space, but also given them more opportunities to avoid taxation. The research based on the results of an analytical study by Polyvana Yu., Matviichuk D., Zahoriichuk T. "Taxation of digital services as an alternative tool in the implementation of fiscal policy in the context of global trends", carried out under a joint project of the Ministry of Development of Economy, Trade and Agriculture of Ukraine and Universities titled "Synergy of knowledge, experience and creativity for the future" (April, 2020). In the process of writing the paper, the methods of theoretical generalization, system analysis, quantitative analysis of economic indicators have been used. The article uses comparison method for analyzing approaches to digital taxation in different countries of the world, as well as an empirical method for forming the scientific novelty of the article.

Literature overview. The development of the digital economy is actively discussed in the domestic and foreign scientific literature, but in domestic sources there has been paid not enough attention to the problems of digital taxation. The digital economy is the result of a transformative process brought by information and communication technology [12] and it raises broader tax challenges for policy makers. Some of current researchers [13] note that equalization taxes, including the EU "Digital Services Tax", have a number of potential disadvantages and shortcomings, including their negative impact on growth, innovation and productivity, non-neutrality, double taxation, and problems in compliance and administration. At the current stage of economic development, the European Commission and the OECD are working on digital taxation issues. The OECD has developed "The program for the development of coordinated solutions to address the challenges associated with the digitalization of the economy", and the European Commission is the developer of a Directive on digital taxation of the income of digital corporations. Anyway, more than 96 countries have already implemented legislation on direct or indirect taxes on digital economy [14]. That is why the relevance of such research is proved.

Results. Experts note that digitalization, artificial intelligence and robotics will be the main drivers of global economic growth until 2030. In addition, they predict that in 2025 , almost $1 / 4$ of the world's GDP will be accounted for by the digital economy due to the digital economy industry (now, according to various estimates, it is from 4.5 to $15.5 \%$ ). Therefore, it is not surprising that since 2015, issues of the digital economy have been on the agenda of the annual EU summits.

It should be noted that it is the digital service providers - Facebook, Apple, Amazon, Netflix, Google and Microsoft - that have the highest level of market capitalization in the global financial market (4.5 trillion USD). They are worth more than 1000 companies listed on the London stock exchange. However, none of the six is an example of responsible tax behavior. At the same time, Amazon paid only 3.4 billion USD in income tax over this 
decade, while Apple paid 93.8 billion USD and Microsoft paid 46.9 billion USD. This is a significant variance, especially since Amazon's revenue for this period exceeded Microsoft's profit by almost 80 billion USD.

Thus, empirical research confirms that large multinational companies (mainly from the digital sector) pay relatively low taxes in high-tax countries.

Previously, the OECD estimated that governments around the world lose $4-10 \%$ of total corporate income tax revenue annually, or 100-240 billion USD. According to the latest Euractiv data, according to statistics of tax havens such as Bermuda or Ireland, about $40 \%$ of the profits of multinational companies avoid taxation. Thus, the EU loses $20 \%$ of its revenue from digital companies.

Addressing the challenges of international taxation of high-tech (digital) businesses is one of the objectives of Action 1 of the BEPS counteraction Plan. According to the current international tax rules, the country where consumers are located has limited rights regarding the taxation of profits from remote activities of a foreign company that does not have a presence in this country. The result of the work of the OECD was the approval of The program for the development of coordinated solutions to address the challenges associated with the digitalization of the economy in May, 2019.

The proposals significantly change the approach to the distribution of income tax rights between the country of source of income and the country of residence of the person who receives them. In particular, the right to impose a significant share of revenue is transferred to the jurisdiction where consumers or users of the product are located (the so-called "consumer market jurisdiction" or market jurisdiction), provided that the main added value of the product is created by the business through contacts (including remote) with the consumer.

Therefore, a business that operates remotely and currently does not pay taxes in the country of the consumer of the product or service, under the new rules, may be subject to taxation in this country, since it will be considered such that it has a close connection with the jurisdiction of the consumer market. If a business has a local business unit in a consumer market country (a distribution subsidiary or representative office), a portion of the group's net profit may be considered the profit of that unit, even if the unit's functions in the consumer market country are limited. In other words, if a business has a close connection with a jurisdiction for having a significant consumer base there, then the jurisdiction gets the right to tax not only the profit associated with the performance of routine functions of the local business unit, but also part of the group profit associated with the performance of essential (non-routine) functions for the business.

The rules of the European Union are aimed at creating a tax regime that would be fair in taxing the income of digital corporations and favorably affect the growth of business activity in general. The European Commis- sion has presented a number of measures aimed at ensuring fair and efficient taxation of digital businesses operating within the EU. The package includes both interim measures in the form of a $3 \%$ tax on digital services from income, and a long-term solution that introduces the concept of digital permanent representation. Comparing with domestic practice, the understanding of a permanent representative office as a single entity of the national tax system and a non-resident does not take into account the specifics of digital economy companies, which means that the activities of such companies on the territory of Ukraine are carried out without proper taxation.

The goal of creating innovations in the tax sphere is efficiency in revenue collection, namely, to collect the maximum amount of income with minimal costs for the state. According to the European Commission's interpretation, the digital services tax will apply to two main types of services that could not exist in their current form without user participation. A common feature of these taxes is that they depend heavily on the use of user participation or data received from users:

- firstly, it will cover services where the main value is created through user data, or through advertising, or through the sale of data collected by companies such as social media and search engines;

- secondly, it will cover digital platform delivery services that facilitate interaction between users who can then exchange goods and services through the platform (for example, peer-to-peer sales programs).

The proposal of the Directive on a common digital services tax system on income derived from the provision of certain digital services is intended to avoid potential disagreements arising within the EU as a result of unilateral initiatives by Member States, and offers a coordinated approach to the taxation of income from certain digital services.

The new digital services tax (DST) is applied from January 1, 2020 at a flat rate of 3\% of gross revenue from certain digital services, including: the delivery of advertising space; providing access to trading platforms that facilitate transactions directly between users; transmitting collected user data that deliver digital content or payment services.

DST will be applied to enterprises that collectively meet certain indicators: have a total annual revenue in the world of more than 750 million EUR and a total annual revenue from digital services in the EU of more than 50 million EUR.

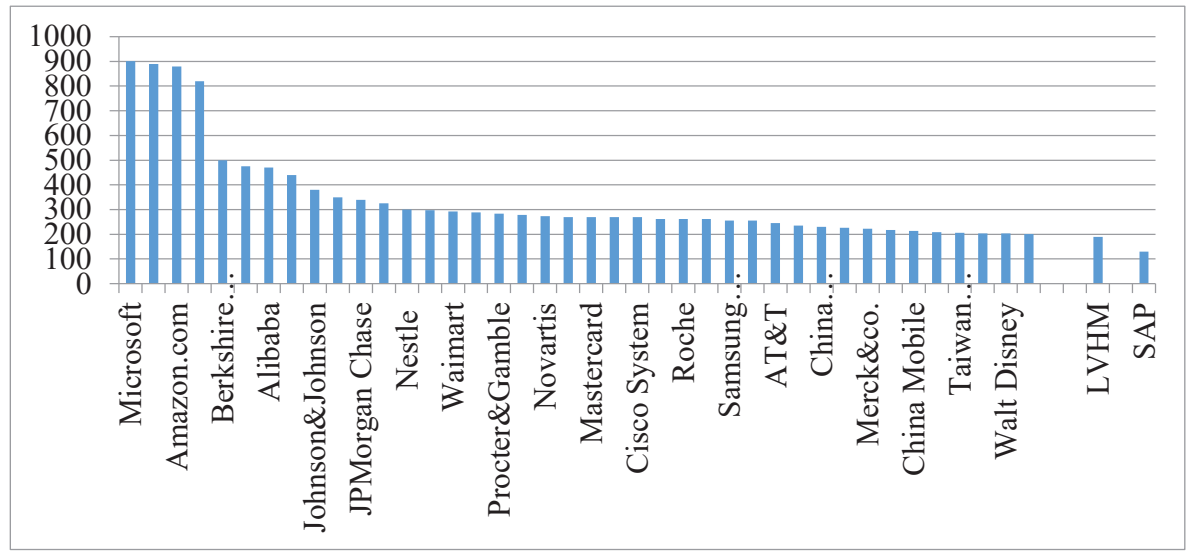

Figure 1 - Global Top 100 companies by market capitalization (\$bn), July 2019

Source: own illustration based on [1] 
The Directive also provides for cooperation between member States in the form of a "single window" mechanism, which allows taxpayers to have a single point of contact to meet all administrative obligations in relation to the new tax (i.e., identification, reporting and payment). In addition, taxpayers should be able to deduct VAT from their corporate income tax liability in order to partially mitigate double taxation. The Directive proposal, which sets out rules related to the taxation of corporate capital in a significant digital presence, has a broader scope than the digital services tax, and is intended to introduce a taxable link for digital businesses operating within the EU, without any or only limited physical presence. It also sets out principles for attributing profits to businesses with such a "significant digital presence."

The concept of "significant digital presence" is based on the existing concept of permanent representation and covers any digital platform, such as a website or mobile app, that meets one of the following criteria: annual revenue from the provision of digital services in a particular member state exceeds 7 million EUR; the annual number of users of such services exceeds 100000 ; or the annual number of online contracts concluded with users in a certain state exceeds 3000 .

The proposed rules for profit distribution are mainly based on the existing structure of the OECD, applied to permanent missions, and suggest profit distribution as the best method. The measures proposed by the European Commission include Recommendations to Member States to amend their double taxation treaties with third countries so that the above rules also apply to companies that are not the EU members. Last year (2019), The European Union (EU) has unveiled a digital tax proposal. However, the EU could not reach agreement on a proposal to tax digital services. As of January, 2020, Austria, France, Hungary, Italy and Turkey have introduced DST. Belgium, the Czech Republic, Slovakia, Spain and the United Kingdom have published proposals to adopt DST, while Latvia, Norway and Slovenia have officially announced or revealed intentions to introduce the tax.

The proposed and implemented DSTs differ significantly in their structure. For example, while Austria and Hungary only tax revenue from Internet advertising, France's tax base is much broader, including revenue from providing a digital interface, targeted advertising, and transmitting data collected about users for advertising purposes. Tax rates range from $2 \%$ in the UK to $7.5 \%$ in both Hungary and Turkey (although the tax rate in Hungary is temporarily reduced to $0 \%$ ).

The OECD is currently working on an international solution on digital taxation. Some countries have recently taken unilateral measures to introduce a tax on digital services (Table 1).

Table 1 - Taxes on digital services/products in the European countries, 2020

\begin{tabular}{|c|c|c|c|c|c|}
\hline Country & Tax Rate & Scope & $\begin{array}{l}\text { Global Revenue } \\
\text { Threshold }\end{array}$ & $\begin{array}{c}\text { Domestic Revenue } \\
\text { Threshold }\end{array}$ & Status \\
\hline Austria (AT) & $5 \%$ & Online advertising & 750 million EUR & 25 million EUR & Implemented \\
\hline Belgium (BE) & $3 \%$ & Selling of user data & 750 million EUR & 5 million EUR & Proposed \\
\hline $\begin{array}{c}\text { Czech } \\
\text { Republic (CZ) }\end{array}$ & $5 \%$ & $\begin{array}{l}\text { Targeted advertising; Use of multilateral } \\
\text { digital interfaces; Provision of user data } \\
\text { (additional thresholds apply) }\end{array}$ & 750 million EUR & $\begin{array}{l}100 \text { million CZK } \\
(4 \text { million USD) }\end{array}$ & Proposed \\
\hline France (FR) & $3 \%$ & $\begin{array}{c}\text { Provision of a digital interface; } \\
\text { Advertising services based on users' data }\end{array}$ & 750 million EUR & 25 million EUR & Implemented \\
\hline Hungary (HU) & $7.5 \%$ & Advertising revenue & $\begin{array}{l}100 \text { million HUF } \\
\text { (344 } 000 \text { USD) }\end{array}$ & N/A & Implemented \\
\hline Italy (IT) & $3 \%$ & $\begin{array}{c}\text { Advertising on a digital interface; } \\
\text { Multilateral digital interface that allows } \\
\text { users to buy/sell goods and services; } \\
\text { Transmission of user data generated } \\
\text { from using a digital interface }\end{array}$ & 750 million EUR & 5.5 million EUR & Implemented \\
\hline Latvia (LV) & $3 \%$ & - & - & - & $\begin{array}{c}\text { Announced/ } \\
\text { Shows Intention }\end{array}$ \\
\hline Norway (NO) & - & - & - & - & $\begin{array}{c}\text { Announced/ } \\
\text { Shows Intentions }\end{array}$ \\
\hline Poland (PL) & $1.5 \%$ & $\begin{array}{c}\text { Audiovisual media service and } \\
\text { audiovisual commercial communication }\end{array}$ & - & - & Approved \\
\hline Slovakia (SK) & - & - & - & - & Proposed \\
\hline Slovenia (SI) & - & - & - & - & $\begin{array}{c}\text { Announced/ } \\
\text { Shows Intentions }\end{array}$ \\
\hline Spain (ES) & $3 \%$ & $\begin{array}{l}\text { Online advertising services; Sale of } \\
\text { online advertising; Sale of user data }\end{array}$ & 750 million EUR & 3 million EUR & Proposed \\
\hline Turkey (TR) & $7.5 \%$ & $\begin{array}{c}\text { Online services including } \\
\text { advertisements, sales of content, and } \\
\text { paid services on social media websites }\end{array}$ & 750 million EUR & $\begin{array}{l}20 \text { million TRY } \\
\text { (4 million USD) }\end{array}$ & Implemented \\
\hline $\begin{array}{l}\text { United } \\
\text { Kingdom } \\
(\mathrm{GB})\end{array}$ & $2 \%$ & $\begin{array}{l}\text { Social media platforms } \\
\text { Internet search engine } \\
\text { Online marketplace }\end{array}$ & $\begin{array}{l}500 \text { million GBP } \\
(638 \text { million USD) }\end{array}$ & $\begin{array}{l}25 \text { million GBP } \\
\text { (32 million USD) }\end{array}$ & Implemented \\
\hline
\end{tabular}

Source: [15] 
The OECD is currently working on an international solution on digital taxation. Some countries have recently taken unilateral measures to introduce a tax on digital services. For example, France has introduced the so-called "GAFA tax" named after Google, Apple, Facebook and Amazon to ensure global Internet giants pay a fair share of taxes for their huge business operations in Europe; this tax is applied from January 1, 2019 and has already increased the budget revenues of the Federal Budget by $23 \%$. France is one of the last countries to apply a tax on digital services, despite the fact that the USA has launched an investigation into the discriminatory nature of the tax [8]. Hungary has previously applied a type of tax on digital services. Austria, Belgium, the Czech Republic, Italy, Poland, Slovenia, Spain, Turkey and the United Kingdom have all either announced or published a proposal to introduce a tax on digital services, and Poland recently suspended its work on a tax on digital services.

In addition, in Italy, the Finance law of 2018 introduced a web tax that applies from January, 2019. The 3\% tax applies to the Internet services that are characterized by minimal human intervention and the use of technologies provided by residents and non-residents to local business entities. The new tax was paid by the buyers of the service. The minimum threshold is 3000 transactions / year. The special turnover tax does not take into account expenses and is not subject to income tax. Italy has also adopted a new transfer pricing rule that provides for the use of valuation methods other than cost-based indicators to determine the prices of digital transactions on a long-term basis.
If we compare the competitiveness of the tax systems of countries that use digital services taxation with their global competitiveness index (Figure 2), the result was ambiguous because the countries occupy the following places: Austria - 12, France - 36, Hungary - 14, Italy - 34 and Turkey - 13 introduced DST. Belgium - 27, the Czech Republic - 10, Slovakia - 11, Spain - 23, Great Britain 25, Latvia - 3, Norway - 19, Slovenia - 20.

In other words, we can conclude that there is no primary relationship between the competitiveness of the tax system and the introduction of alternative taxes; taxation of the digital economy is a modern challenge, a new niche in expanding the tax base, countering the erosion of existing tax bases in order to avoid taxation, and an alternative source of replenishment of budget revenues in various countries. This means that this is a convincing argument for the possibility of implementing and adapting global tax trends into domestic tax policy.

In order to identify which taxes on digital services can be used in Ukraine, it is necessary to analyze the state of the IT market in Ukraine (Figure 3). The IT sector in Ukraine, in particular the domestic market, is represented as the following proportion: Hardware $-83 \%$; Software $-7 \%$; Services $-10 \%$. We note that almost the entire IT sector in Ukraine is represented in the form of hardware, that is, the design of computer equipment, but the development of software and services takes up only $17 \%$ of the domestic IT market in Ukraine. From 2011 to 2018, the export of IT services has a clear growth

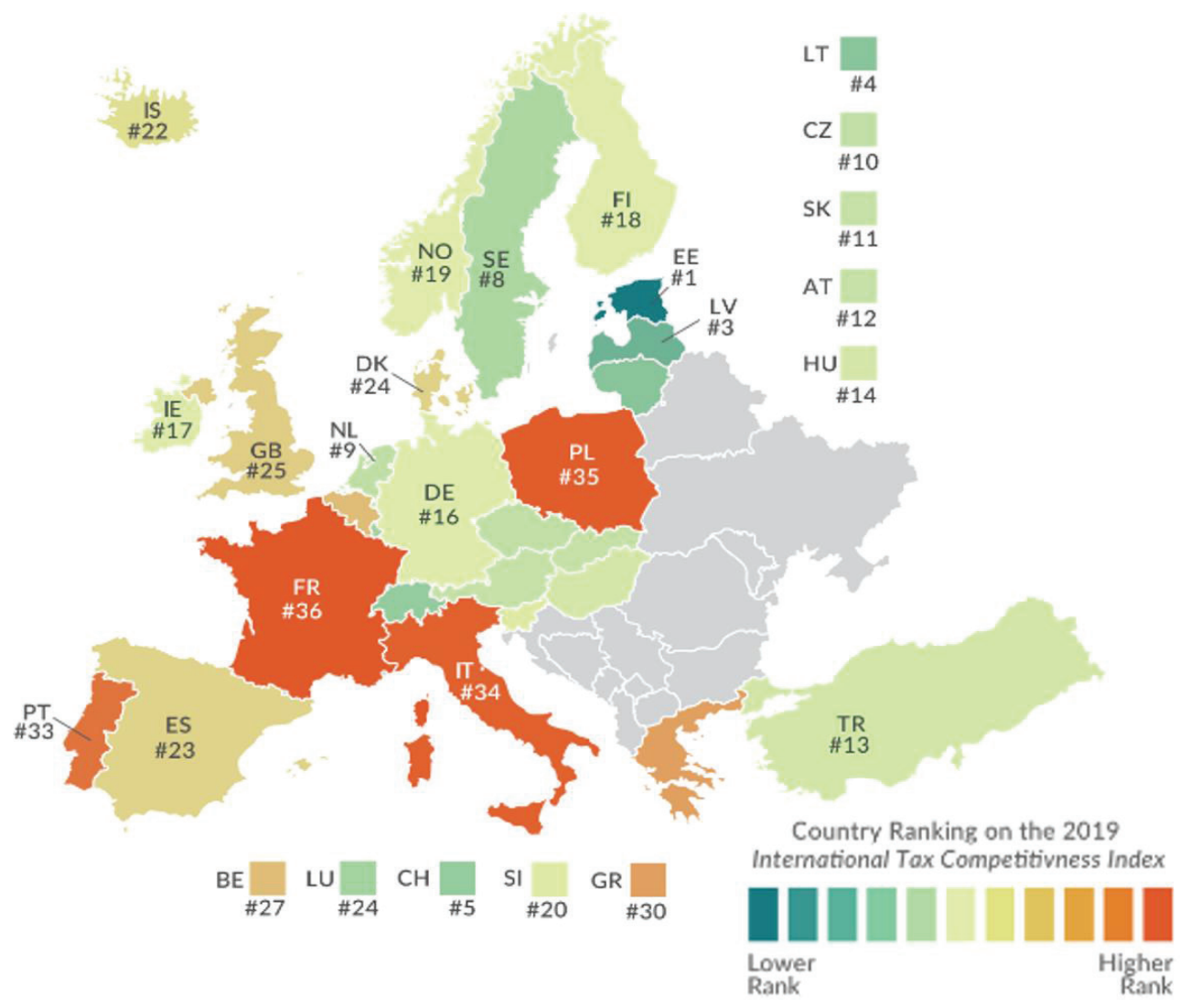

Figure 2 - Rating of the European countries on the International Tax Competitiveness Index 


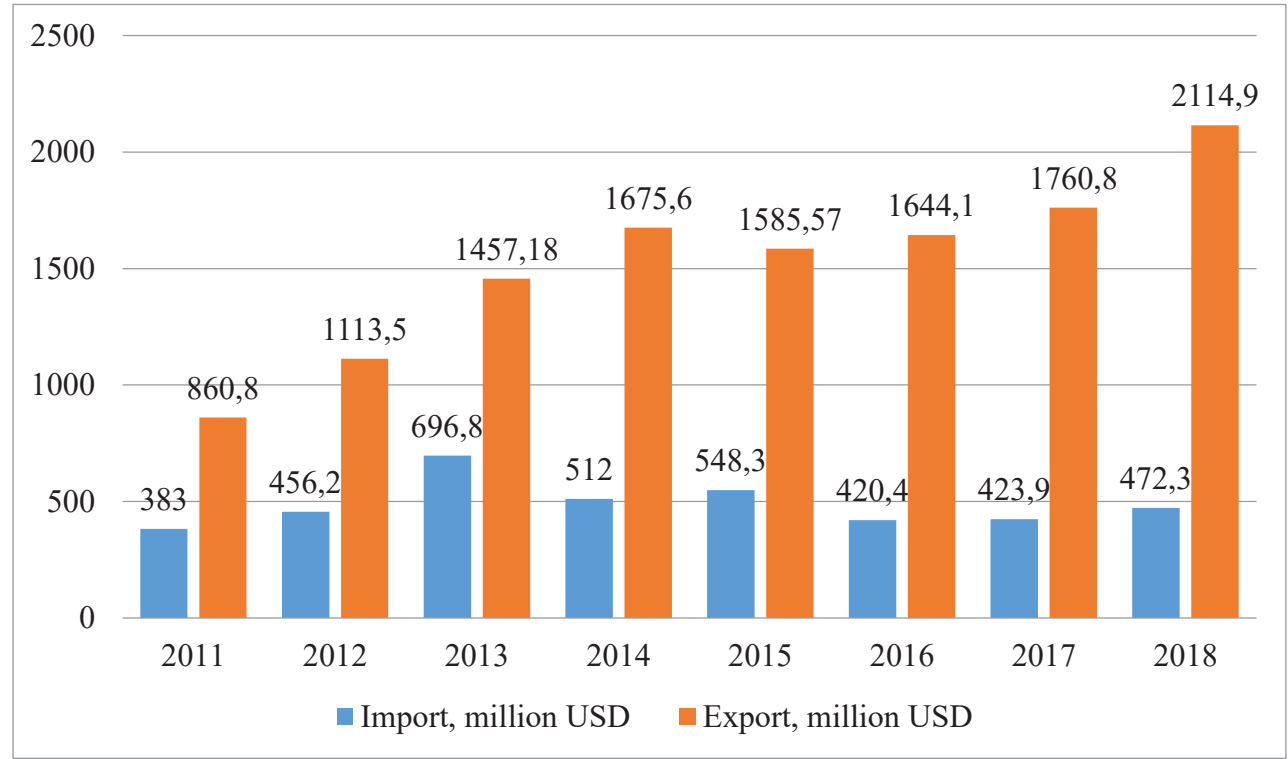

Figure 3 - Foreign trade in IT services in Ukraine (2011-2018)

Source: own illustration based on [11]

trend. During the analyzed period, there was an increase of $145.6 \%$ (1254.1 million USD). The largest increase in this period took place, namely from 2017 to 2018 by 354.1 million USD (by $20.1 \%$ ).

From 2011 to 2018, the volume of IT services in the export structure increases significantly. So, in 2017 , computer services took the 3 rd place among the exports of services from Ukraine after services for processing goods in the country and pipeline transport, and according to the results of the first half of 2018, they overtook pipeline transport and became the second largest industry for the export of services. The growth of the industry is visible in various independent metrics (revenue, receipts, personnel) and at the end of 2018 it is in the range of $20-29 \%$.

The development of the IT industry in Ukraine is significantly ahead of the average pace of development of the segment in the world. More than 100 representatives of the list of the most successful companies in the world "Fortune 500" are loyal customers of the domestic IT business, the leading international organization Global Sourcing Association notes Ukraine as the best country-provider of IT services in the UK, the influential American business magazine Inc. includes Ukrainian companies in the lists of the most dynamically developing. However, the taxation aspect of the industry remains relevant due to the existing unresolved issues.

In general, Ukraine has a wide range of strengths and opportunities regarding the taxation of digital services through the stabilization of the socio-economic situation and possibilities to improve the investment climate and ensuring equal rights and opportunities of market participants, free competition by imposing a tax on the capital, the overall high level of training of it specialists. The NBU's activities regarding the lifting of restrictions in the field of currency regulation allowed to manage foreign exchange receipts for specialists and IT companies that send goods and services for export and receive income in foreign cur- rency. The ban on certain products and social networks led to the orientation of businesses and citizens to domestic and foreign analogues, increased demand and stimulated the domestic market.

The existing problems can be solved at the legislative level mainly due to changes to the Tax code in terms of difficulties regarding the application of existing tax benefits (valid until 2023), as well as the taxation of income of IT professionals working as sole proprietors. The issue of piracy, migration, differentiation of types of services and market participants concern other branches of law. Ukraine is one of the world leaders in terms of pirated content due to the low solvency of the population regarding the use of content.

As for the concentration of IT companies, the problem is that in this way the single tax is concentrated at the level of the relevant local budgets (Kyiv, Kharkiv, Lviv), students and young people migrate within the country or cannot be implemented in their region, regions lose financial and human resources, since the level of material incentives for IT professionals is much higher than average. The introduction of the General taxation conditions may lead to the exit of giants from the Ukrainian market to tax havens, and the increase in spending on digital services will negatively affect the standard of living of citizens.

The issue of tax credits, preferential loans, tax holidays for IT and high-tech startups remains open, as well as access to foreign capital markets - attracting investment - remains a difficult process due to high economic risks, constant changes in legislation, differences in intellectual property law, accounting standards, and so on.

Discussion and conclusions. Taking into account the analysis of the market in Ukraine, in our opinion, it is now possible to gradually implement the following types of taxes on digital services, in particular:

- Tax on Internet services provided by residents, as implemented in Italy. As for the tax rate, it can vary from 4 to $5 \%$ of the received income. For Ukraine, you cannot apply the rate if you cooperate with universities, attract 
Ukrainian graduates, create digital products for the state (based on Prozorro tenders).

- Tax on "GAFA" and other non-resident companies in the range of $1-2 \%$ of revenue, following the example of France (for us, the percentage is lower, because the business conditions are objectively worse) because VAT for non-residents has a number of additional problems of administration and payment;

- Create a separate group of single tax payers for outsourcers and IT professionals who register as the sole proprietors with an increased income limit, but force them to pay more. The income of specialists in this field is in several times higher than the average in the country. The income of the sole proprietors who were in labor relations with companies exceeded the average salary by 7.8 times, and the size of the single tax was 3.4 times more than the amount of personal income tax per 1 employee. Therefore, we consider it appropriate to raise the rate to $8-10 \%$ of revenue, respectively, additional funds will go to local budgets and help the development of regions, and the estimated additional charges will depend on the growth rate of the market. In addition, we consider it appropriate to exempt startups from taxation for the first 2-3 years of their existence.

\section{References:}

1. Prof. A. Heinemann. "Digital Platform Economies and Taxation: Background and Trends in Digital Taxation and the Proposal of the European Commission” EU Commission (2018), Factsheet, Brussels, March 21, 2018. (August, 2019).

2. Information technology industry in Ukraine. Available at: http://publications.chamber.ua/2018/IT/the-infographics-report-itindustry-of-ukraine-2017.pdf (accessed 15 February 2020).

3. OECD (2020), Statement by the OECD/G20 Inclusive Framework on BEPS on the Two-Pillar Approach to Address the Tax Challenges Arising from the Digitalization of the Economy - January 2020, OECD/G20 Inclusive Framework on BEPS, OECD, Paris. Available at: www.oecd.org/tax/beps/statement-by-the-oecd-g20-inclusive-framework-on-beps-january-2020.pdf (accessed 15 February 2020).

4. KPMG, "Taxation of the digitalized economy," Jan. 23, 2020, Available at: https://tax.kpmg.us/content/dam/tax/en/pdfs/2020/ digitalized-economy-taxation-developments-summary.pdf (accessed 18 February 2020).

5. Dynamics of foreign trade in services by type. Available at: http://www.ukrstat.gov.ua/operativ/operativ2008/zd/dseip/ dseip2007_u.htm (accessed 18 February 2020).

6. Explanatory note to the draft Law of Ukraine "on amendments to the Tax code of Ukraine regarding the taxation of valueadded tax on electronic services supplied by non-residents to individuals whose place of delivery is located on the customs territory of Ukraine". Available at: http://w1.c1.rada.gov.ua/pls/zweb2/webproc34?id=\&pf3511=67703\&pf35401=515695 (accessed 25 February 2020).

7. VAT on digital services (MOSS scheme). Available at: https://europa.eu/youreurope/business/taxation/vat/vat-digital-servicesmoss-scheme/index en.htm (accessed 2 March 2020).

8. Digital Tax Around The World: What To Know About New Tax Rules. Available at: https://quaderno.io/blog/digital-taxesaround-world-know-new-tax-rules/ (accessed 3 March 2020).

9. Section 301 Investigation Report on France's Digital Services Tax. Available at: https://ustr.gov/sites/default/files/Report On France\%27s_Digital_Services_Tax.pdf (accessed 25 February 2020).

10. International Tax Competitiveness Index, 2019. Available at: https://taxfoundation.org/publications/international-taxcompetitiveness-Index/ (accessed 3 March 2020).

11. State statistics service of Ukraine. Available at: http://www.ukrstat.gov.ua (accessed 2 March 2020).

12. Addressing the Tax Challenges of the Digital Economy // OECD/G20 Base Erosion and Profit Shifting Project. Available at: https://www.oecd-ilibrary.org/docserver/9789264218789-en.pdf?expires=1592581443\&id=id\&accname=guest\&checksum=9A0F6B EDF8CB602671D3987EE9BE384A (accessed 25 February 2020).

13. G. Kofler, J. Sinnig (2019) Equalization taxes and the EU's 'digital services tax'. INTERTAX, Volume 47, Issue 2, Kluwer Law International BV, The Netherlands

14. Taxation of the digitalized economy: developments summary. Updated: June 12, 2020. Available at: https://tax.kpmg.us/ content/dam/tax/en/pdfs/2020/digitalized-economy-taxation-developments-summary.pdf (accessed 3 March 2020).

15. Asen E. (2020) What European OECD Countries Are Doing about Digital Services Taxes, Updated: June 20, 2020. Available at:: https://taxfoundation.org/digital-tax-europe-2020/ (Accessed 25 June 2020). 
Котіна Г.М.

Степура М.М.

Поливана Ю.М.

ДВНЗ «Київський національний економічний університет імені Вадима Гетьмана»

\section{ОПОДАТКУВАННЯ ЦИФРОВИХ ПОСЛУГ ЯК АЛЬТЕРНАТИВНИЙ ІНСТРУМЕНТ ФІСКАЛЬНОЇ ПОЛІТИКИ В ГЛОБАЛЬНОМУ СВІТІ}

В статті досліджено світову практику впровадження податків на електронні послуги та можливості впровадження балануючих податків в Украӥні. Метою створення інновачій у податковій сфері є ефективність у мобілізації доходів бюджету, а саме збирати максимальну суму податкових надходжень з мінімальними втратами для держави. Зважаючи на мобільність традииійної податкової бази, глобалізацію економічного простору, активний розвиток інформаційних продуктів і послуг, високу вартість иифрових корпорацій на фінансовому ринку, уряди різних країн вдаються до пошуку ефективних фіскальних інструментів для забезпечення конкурентоспроможності податкових систем. В статті встановлено відсутність первинної залежності між конкурентоспроможністю податкової системи та впровадженням альтернативних податків - оподаткуванням ичифрової економіки. Незважаючи на існування потениійних недоліків, включаючи їх негативний вплив на ріст, інновації та продуктивність праці, нейтралітет, можливості подвійного оподаткування та проблеми у дотриманні та адмініструванні, ие виклик сьогодення, нова ніша в розширенні податкової бази, протидія розмиванню існуючих податкових баз з метою уникнення від оподаткування та альтернативне джерело поповнення доходів бюджетів різних країн. А отже, ие є переконливим аргументом на рахунок можливості імплементації та адаптаиії світових податкових трендів у вітчизняну податкову політику. Зокрема, створення податкового режиму, який би був справедливий в оподаткуванні доходів ичифрових корпорацій та сприятливо впливав на зростання активності підприємницької діяльності в цілому. Статтю підготовлено за результатами аналітичного дослідження Поливаної Ю., Матвійчук Д., Загорійчук Т. "Оподаткування изифрових послуг як альтернативний інструмент в реалізації бюджетно-податкової політики в контексті глобальних трендів», виконаного в рамках спільного проекту Міністерства розвитку економіки, торгівлі та сільського господарства Украӥни та вищих навчальніх закладів Украӥни «Синергія знань, досвіду та креативності заради майбутнього» (квітень 2020).

Ключові слова: податок, оподаткування ичифрових послуг, балансуючі податки, державні фінанси, доходи, податкове право. 